\title{
In an Ileal Diverticulum (Meckel's Diverticulum) - Gastric Perforation: Report of a Fatal Case
}

\author{
Divertículo Ileal (Divertículo de Meckel) - Perforación Gástrica: Reporte de un Caso Fatal
}

\author{
"Sujatha Narayana Moorthy \& ** Rekha Arcot
}

MOORTHY, S. N. \& ARCOT, R. In a ileal diverticulum (Meckel's diverticulum) - Gastric perforation: Report of a fatal case. Int. J. Morphol., 28(4):1273-1276, 2010.

SUMMARY: The ileal diverticulum (Meckel's diverticulum) is a congenital outpouching located in the distal ileum which occurs due to the failure of obliteration of the yolk stalk. The peak age in which this anomaly is mostly found is the pediatric age especially below the age of two. Hence it is noted as an uncommon cause of intestinal obstruction and fatality in adult life. We present a case of a 26 year old man with abdominal pain and vomiting for 6 days associated fever for 3 days. Emergency laparotomy revealed ileal diverticulitis with small bowel obstruction. Ileal diverculectomy with ileal resection and ileoileal anastamosis was performed. However, the patient developed renal dysfunction leading to Multiorgan Dysfunction Syndrome and died on the fourth post operative day. This anatomic anomaly is rare in adult patients and is difficult to diagnose early due to its bizarre presentation resulting in high mortality in them. Hence we find this case of interest.

KEY WORDS: Ileal diverticulum; Meckel's diverticulum; Gastric ectopic rest; Adults; Death.

\section{INTRODUCTION}

Ileal diverticulum also known as Meckel's diverticulum is the most prevalent congenital abnormality of the gastrointestinal tract (Turgeon \& Barnett, 1990). It is a condition that results due to the persistence of the proximal part of the vitellointestinal duct. This duct, which connects the midgut to the yolk-sac, normally disappears by the sixth week of intrauterine life. Failure of its obliteration leads to various anomalies namely umbilical polyp, umbilical sinus, patent vitellointestinal duct and most importantly the ileal diverticulum. A review of literature shows that this developmental abnormality arises in about $2 \%$ of the population (Leijonmarck et al., 1986). It is reported that this diverticulum is mostly found in children and occurs equally in both the sexes (Arnold \& Pellicane, 1997). Soltero \& Bill (1976) pointed out that the incidence of the ileal diverticulum decreases with age. Hence, if present in adults, it becomes a rare cause of intestinal obstruction.

While laparotomy, biopsy, Ultrasonography (USG) abdomen, Superior Mesentric Angiography are used to diagnose ileal diverticulum, the investigation of choice to detect a heterotopic rest within the diverticulum proves to be Techtinium scan (Williams, 1981). Surgical intervention that brings the ultimate cure for ileal diverticulum is dependent on the patient's presentation. It has been reported that the risk of postoperative complications following the excision of this diverticulum is about $10 \%$ (Moore \& Johnston, 1976).

\section{CASE REPORT}

This is a case of a twenty six year old male patient who was brought to the casualty with complaints of nonradiating abdominal pain and severe vomiting for about one week, which was associated with fever for three days. Prior to this visit, the patient had been evaluated with USG abdomen which suggested features of acute appendicitis. It is also noted that the patient has had complaints of non localised abdominal pain which was on and off for the past three years. On examination the patient was found to have altered sensorium, tachycardia and unrecordable blood pressure.

The patient was immediately intubated and an

* M.B.B.S Final Year, Sri Ramachandra Medical College and Research Institute, India.

***M.S. General Surgery, Associate Professor of Surgery, Sri Ramachandra Medical College and Research Institute, India. 
emergency laparotomy was done which revealed ileal diverticulitis with small bowel obstruction. The diverticulum was located at the terminal ileum with adhesions to the sigmoid colon. While mobilising the base, the diverticulum perforated on touch which lead to the pouring of the ileal contents into the peritoneal cavity. Immediately suction was performed. It was observed that the omentum which had a compromised vascularity was found to be shifted towards the right ileac fossa. The surgical procedure involved local ileal resection with ileoileal anastamosis. Following the surgery a peritoneal wash was performed and a right abdominal flank drain was placed. After closing the abdomen in layers, the patient was shifted to the intensive care unit for further monitoring. Hence the major finding of the surgery was a perforated ileal diverticulum (Fig. 1). In the post operative period patient developed renal dysfunction leading to Multiorgan Dysfunction Syndrome (MODS) and died on the fourth post operative day.

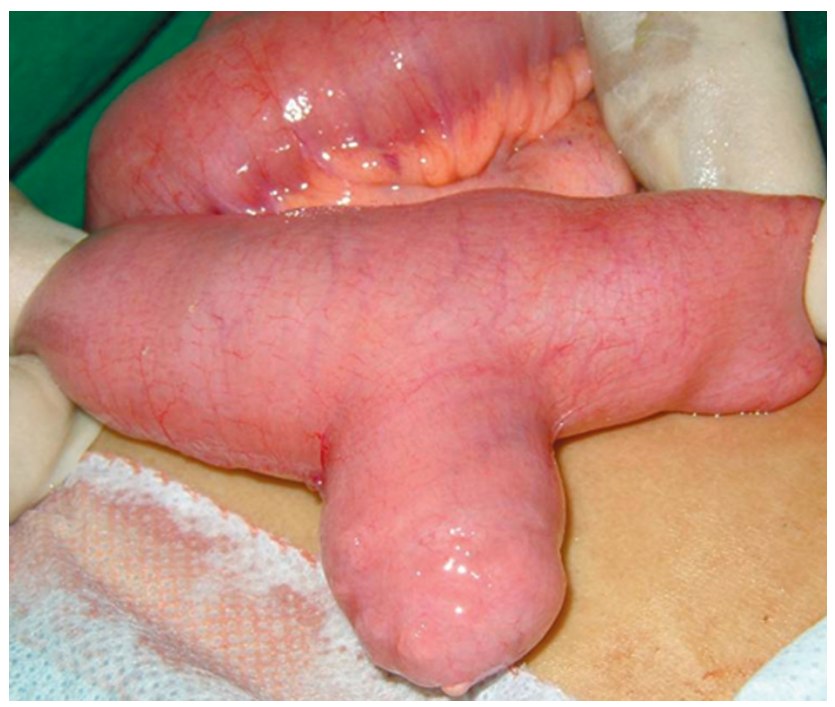

Fig. 1. Ileal diverticulum (Meckel's diverticulum).

\section{DISCUSSION}

Ileal diverticulum is an embryological abnormality which belongs to a spectrum of anomalies that occurs due to a persistent yolk stalk. Wilhelm Fabricius Hildanus was the first to describe the diverticulum in the year 1598 (Haber, 1947). However the diverticulum is named after Johann Friedrich Meckel who first reported its anatomy and embryology (Meckel, 1809). Over fifty years about 1467 cases from various age groups have been reported (Park $e t$ al., 2005). However reports on ileal diverticulum being fatal in adults are rare.

The diverticulum is known to classically follow the rule of 2's. It occurs in about $2 \%$ subjects measuring about
$2 \mathrm{~cm}$ in length and is situated about 2 feet away from the ileoceacal valve. It commonly presents in the first two years of life may contain two types of epithelial tissue. However an exception has been reported where the ileal diverticulum measuring $4.3 \mathrm{~cm} \mathrm{x} 2.1 \mathrm{~cm}$, presented itself $58 \mathrm{~cm}$ proximal to the ileoceacal junction (Madhyastha et al., 2007). In this present study, the diverticulum found in the patient was about $3 \mathrm{~cm}$ long. Histologically, it contains all the three layers of the intestinal wall namely mucosa, submucosa and muscularis propria. Nevertheless literature has reported that heterotopic rests of gastric and colonic mucosa or pancreatic, duodenal, jejunal, hepatic or endometrial tissue may be present (DiGiacomo \& Cottone, 1993; Williams; Garretson \& Frederich, 1990). Gastric and colonic ectopic tissues can lead to complications like ulceration of the diverticulum which causes an upper gastrointestinal bleed. This is attributed to the $\mathrm{pH}$ variation in the diverticulum due to the presence the ectopic tissue.

The complications that can be present are inflammation, perforation, vesiculodiverticular fistula, intussusception, volvulus, hernia and malignancy being the rarest complication. It is discerned that malignancy is found only in $0.45-0.50 \%$ of the patients (DiGiacomo \& Cottone). The most common benign tumour that is found to complicate a ileal diverticulum is leiomyoma (Weinstein et al., 1963). Of the malignant tumours, sarcoma is the commonest, followed by carcinoids and adenocarcinomas (DiGiacomo \& Cottone). The first report of a sarcoma was a fibromyosarcoma arising in a ileal diverticulum by Fried in 1902 (Fried, 1902). Most of the patients are asymptomatic and hence are diagnosed incidentally. If symptomatic, they present with symptoms that are similar to that of acute appendicitis like nausea, vomiting, pyrexia and abdominal pain. In patients with ileal diverticulum with upper gastrointestinal bleed, hematochezia or melena is usually present. However, it is pointed out that the most common presentation is obstruction in pediatrics and bleeding in adults (Park et al.).

Investigation most often is laparoscopy or laparotomy in case of an incidentally found asymptomatic diverticulum (Malik et al., 2010). When symptomatic, the ideal investigation that can be performed is Technetium Tc $99 \mathrm{~m}-$ pertechnate radioisotope scanning. The usage of this scan is based upon the principle of administering pertechnate intravenously which in turn is taken up by the mucussecreting cells of the gastric mucosa present in the ileal diverticula (DiGiacomo \& Cottone). This is called ileal scan. Literature has proved that the scan has a sensitivity of $85 \%$ and a specificity of $95 \%$ in children and the sensitivity falls to $62.5 \%$ and specificity to only $9 \%$ in adults (Schwartz \& Lewis, 1984). Hence the accuracy of the scan can be 
improved by administering a combination of pentagastrin and glucagon thereby leading to an increased uptake of the isotope and cease peristalsis in the patient simultaneously (Hughes et al., 1998). Superior mesenteric angiography may be helpful in patients presenting with acute gastrointestinal bleeding and is effective when blood loss exceeds $0.5 \mathrm{~mL} /$ min. This has an accuracy of about 59\% (Khan et al., 2008). Another useful investigation is a biopsy of the diverticulum tissue. In our patient the histopathological examination of the tissue revealed a ileal diverticulum lined predominantly by gastric epithelium. The base of the diverticulum showed a perforation involving a portion of small intestine. The resected margin of the ileum showed congestion and submucosal oedema.

The approach to treatment of a ileal diverticulum depends on whether it is discovered incidentally or as a result of symptoms. There is a controversy in performing surgery on an asymptomatic diverticulum. A Mayo clinical study revealed that it is advisable to perform surgery on an asymptomatic patient if any one of the following criteria of the patient's age lesser than 50, male sex, length of diverticulum more than $2 \mathrm{~cm}$ or presence of ectopic tissue within the diverticulum is present (Park et al.).

The various surgical approaches are diverticulectomy with suture closure of the base, wedge resection of the intestinal wall containing the diverticulum with suture closure or segmental resection of the intestine, including the diverticulum and end-to-end anastamosis which are often performed on patients complicated with haemorrhage to ensure adequate excision of the part containing gastric and the ulcerated ileal mucosa. Division of the fibrous band with or without diverticulectomy is also an available option. Recently laparoscopic techniques are increasingly being used for diverticulectomy and intestinal resection. With advancements in technology, therapeutic interventions such as intracorporeal resection or laparoscopic-assisted extracorporeal resection are being performed. Emergency laparoscopic management of ileal diverticulum was preferred in our patient as he had acute symptoms of abdominal pain. Postoperative complications, such as ileus, suture line or intestinal anastomotic leak, intra-abdominal abscess, and pulmonary embolism that occur in about $10 \%$ of the patients are responsible for increased mortality rate (Moore \& Johnston).

\section{CONCLUSION}

The occurrence of ileal diverticulum in pediatric population is not a curiosity but its symptomatic occurrence in an adult is. The ectopic rests of gastric tissue, as seen in this patient, often cause bizarre presentations. Sound knowledge of anatomy, a high index of suspicion and an awareness of unusual presentations are necessary for prompt diagnosis and timely intervention.

ACKNOWLEDGEMENT. S. Vishal is heartily thanked for the technical assistance in the preparation of the manuscript.

MOORTHY, S. N. \& ARCOT, R. Perforación gástrica en un divertículo de ileal (diverticulo de Meckel): Reporte de un caso fatal. Int. J. Morphol., 28(4):1273-1276, 2010.

RESUMEN: El divertículo de ileal o de Meckel es una evaginación congénita en el íleon distal, que se produce debido a la falta de obliteración del conducto vitelino. La edad en que esta anomalía frecuentemente se encuentra es la pediátrica, especialmente en menores de dos años. Por lo tanto, es una causa infrecuente de obstrucción intestinal y de escasa fatalidad en adultos. A continuación presentamos un caso de un hombre de 26 años, que presentaba un cuadro febril de 3 días y dolor abdominal y vómitos durante 6 días. Una laparotomía de emergencia reveló diverticulitis ileal, con obstrucción del intestino delgado. Fue realizada una diverculectomía ileal con resección ileal y anastomosis ileoileal. Sin embargo, el paciente desarrolló insuficiencia renal que condujo a una disfunción multiorgánica y síndrome de muerte al cuarto día postoperatorio. Esta anomalía anatómica es rara observarla en pacientes adultos y difícil de diagnosticar a tiempo, debido a su singular presentación y frecuentemente resulta en una alta mortalidad en estos pacientes.

PALABRAS CLAVE: Divertículo ileal; divertículo de Meckel; Resto gástrico ectópico; Adultos; Muerte.

\section{REFERENCES}

Arnold, J. F. \& Pellicane, J. V. Meckel's diverticulum: a tenyear experience. Am. Surg., 63:354-5, 1997.
DiGiacomo, J. C. \& Cottone, F. J. Surgical treatment of Meckel's diverticulum. South Med. J., 86:671-5, 1993. 
Fried, O. Ein fall von primaren Sarkom des Meckelschen Diveltickels. Bamberg, Handel, 1902.

Garretson, D. C. \& Frederich, M. E. Meckel's diverticulum. Am. Fam. Physician., 42:115-9, 1990.

Haber, J. J. Meckel's diverticulum; review of literature and analytical study of 23 cases with particular emphasis on bowel obstruction. Am. J. Surg., 73:468-85, 1947.

Hughes, J. A.; Hatrick, A. \& Rankin, S. Computed tomography findings in an inflamed meckel diverticulum. Br. J. Radiol., 71:882-3, 1998.

Khan, N. A.; Chandramohan, M. \& McDonald, S. Meckel diverticulum. Radiol. Pediatr., 110:213-7, 2008.

Leijonmarck, C. E.; Bonman-Sandelin, K.; Frisell, J. \& Räf, L. Meckel's diverticulum in the adult. Br. J. Surg., 73:146-9, 1986.

Madhyastha, S.; Prabhu, V. L.; Saralaya, V. \& Prakash. Meckel's diverticulum. A case report. Int. J. Morphol., 25:519-22, 2007.

Malik, A. A.; Shams-ul-Bari; Wani, K. A. \& Khaja, A. R. Meckel's diverticulum-Revisited. Saudi $J$. Gastroenterol., 16:3-7, 2010.

Meckel, J. F. Über die Divertikel am Darmkanal. Archiv. Für. Die. Physiologie., 9:421-53, 1809.

Moore, T. \& Johnston, A. O. Complications of Meckel's diverticulum. Br. J. Surg., 63:453-4, 1976.

Park, J. J.; Wolff, B. G.; Tollefson, M. K.; Walsh, E. E. \& Larson, D. R. Meckel diverticulum: the Mayo Clinic experience with 1476 patients (1950-2002). Ann. Surg., 241:529-33, 2005.

Schwartz, M. J. \& Lewis, J. H. Meckel's diverticulum: pitfalls in scintigraphic detection in the adult. Am. J. Gastroenterol., 79:611-8, 1984.

Soltero, M. J. \&Bill, A. H. The natural history of Meckel's Diverticulum and its relation to incidental removal. A study of 202 cases of diseased Meckel's Diverticulum found in King County, Washington, over a fifteen year period. Am. J. Surg., 132:168-73, 1976.

Turgeon, D. K \& Barnett, J. L. Meckel's diverticulum. Am. J. Gastroenterol., 85:777-81, 1990.
Weinstein, E. C.; Dockerty, M. B. \& Waugh, J. M. Neoplasms of Meckel's Diverticulum: Collective Review. Int. Abstr. Surg., 116:103-11, 1963.

Williams, R. S. Management of Meckel's diverticulum. $B r$. J. Surg., 68:477-80, 1981.

Correspondence to:

Sujatha Narayana Moorthy

617, G2, Sri Ramana Apts., 9th Sector, 51st Street,

K.K. Nagar

Chennai-600078

INDIA

Email: nsujatha88@yahoo.co.in

Received: $21-08-2010$

Accepted: 03-08-2010 